І. І. Кульбовський /к. т. н./, Г. М. Голуб /к. т. н./, Державний університет інфраструктури та

О. С. Гайденко

технологій, м. Київ, Україна

e-mail:golub.galina@ukr.net

\title{
Моделювання інформаційних потоків комп'ютерного моніторингу мереж електропостачання транспорту
}

I. I. Kulbovskyi /Cand. Sci. (Tech.)/, G. M. Golub /Cand. Sci. (Tech.)/, O. S. Haydenko
State University of Infrastructure and

Technologies, Kyiv, Ukraine

e-mail: golub.galina@ukr.net

\section{Modeling of information powers of computer monitoring of the network of electrical supply of transport}

Мета. Розробка моделі інформаційних потоків комп'ютерного моніторингу та управління як невід’ємних складових єдиного інформаційного простору господарства електропостачання залізниці; удосконалення математичних методів організації безперервного моніторингу параметрів функціонування мереж залізниці в процесі постачання електроенергії на тягу поїздів для проведення, контролю роботи електричних мереж і обладнання, ідентифікації аварійних і нормальних режимів роботи електричних мереж у режимі реального часу.

Методика. Розробка і моделювання інформаційної системи комп'ютерного моніторингу та поліпшення контролю роботи електричних мереж і обладнання, ідентифікації аварійних і нормальних режимів роботи електричних мереж у режимі реального часу.

Результати. Розроблено модель систем моніторингу та управління режимами роботи мережі електропостачання, що показує інформаційні зв'язки між компонентами систем і їх об'єктом, а також способи організації синхронно зареєстрованих первинних даних, фрормування їх у вигляді єдиного інформаційного простору.

Наукова новизна. Для проведення, контролю роботи електричних мереж і обладнання, ідентифрікації аварійних і нормальних режимів роботи електричних мереж у режимі реального часу запропоновано математичну модель організації змінного моніторингу параметрів режимів мережі електропостачання залізниць та способи організації синхронно зареєстрованих первинних даних і способи фрормування їх у вигляді єдиного інформаційного простору із загальносистемних позицій як основи оптимізації енергопостачання, поліпшення безпеки, руху і реалізації енергозберігаючих технологій.

Практична значущість. Вирішення проблеми оптимізації енергопостачання, поліпшення безпеки руху та реалізація енергозберігаючих технологій.

Ключові слова: системний аналіз, енергозбереження, автоматизована система управління, модель, комп'ютерний моніторинг, інформаційні потоки, ідентифрікації. (Іл. 1. Бібліогр.: 7 назв.)

Постановка проблеми. У зв'язку з проведенням моніторингу безперервно в реальному часі з' являється необхідність у фіксації великої кількості інформації з датчиків, що потребує великого обсягу пам' яті та зумовлює складність аналізу цієї інформації [1]. Суттєвий інтерес з точки зору аналізу аномальних режимів мережі електропостачання становлять первинні дані, які відображають аварійний процес, післяаварійний режим, і незначна частина даних доаварійного режиму. Це зумовлює необхідність розробки моделей і таких методів безперервного моніторингу, завдяки використанню яких реалізується реєстрація первинної інформації, що відображає синхронно за часом доаномальний, аномальний і післяаномальний процеси.
Аналіз останніх досліджень і публікацій. Ознайомившись 3 працями [1-3], робимо висновок, що моніторинг у вітчизняній електроенергетиці стрімко розвивається під впливом потреб сьогодення, розвитку апаратних засобів і тенденцій у галузі електроенергетики у світі, тому актуальною $\epsilon$ розробка наукових підходів до його організації. Пошук методів організації безперервного моніторингу режимів мереж електропостачання на основі використання сучасних мікропроцесорних засобів сприяв появі великої кількості математичних моделей, методів і алгоритмів реєстрації і формування первинної інформації. Аналіз праць [1-4] показав, що метою сучасного комп' ютерного моніторингу є формування керуючих рішень, що впливатимуть на його об'єкт, моніторинг слід роз- 
глядати разом із функціями аналізу та обробки зібраних даних, тому за таких умов, проводячи дослідження, організацію моніторингу варто розглядати із загальносистемних позицій у межах єдиного інформаційного простору інтелектуальної системи.

Основний матеріал дослідження. Процес моніторингу є невід' ємною базовою складовою процесу автоматизованого керування [4]. Останнім часом у зв' язку з широким впровадженням мікропроцесорних пристроїв та розширенням сфери ix застосування в інтелектуальній енергетиці йде тенденція до розгляду функцій моніторингу та управління як одного цілого. Наприклад, у праці [2], спираючись на те, що базовим поняттям моніторингу у всіх галузях є «спостереження стану об'єкта $з$ метою керування», автори ввели визначення «моніторинг в електроенергетиці» та відзначили, що до цього поняття має належати оцінка стану об'єкта та його прогнозування, що вже є однією $з$ функцій управління. Тому розглядати систему моніторингу (СМ) та автоматизовану систему управління (АСУ) краще в комплексі. Як об'єкт моніторингу та керування розглядатимемо будь-який пристрій, задіяний в інтелектуальній мережі електропостачання, технологічні процеси що проходять у ній, та процеси, які мають істотний на них вплив, а також мережу загалом [3; 4].

Первинні дані від СМ, які реєструються на виходах датчиків мережі електропостачання та силового електроустаткування тягових підстанцій, а також систем релейного та мікропроцесорного захисту різних сегментів електричного комплексу залізниць мережі електропостачання, можуть подаватися в аналоговій та дискретній формах. У вигляді сукупності аналогових сигналів можуть бути представлені, наприклад, значення струмів $I$, частоти змінного струму $f$, напруги $U$, проміжків часу т, вологості, температури, тиску газу високовольтних вимикачів, концентрації газів $\mathrm{H}_{2}, \mathrm{CH}_{4}, \mathrm{C}_{2} \mathrm{H}_{2}, \mathrm{C}_{2} \mathrm{H}_{6}, \mathrm{CO}_{2}, \mathrm{CO}$ в середовищі мастила силових трансформаторів, а також інших аналогових інформаційних сигналів А. Дискретні сигнали $D$ надходять з виходів датчиків систем мікропроцесорного, релейного захисту та інших носіїв інформації. Це може бути, наприклад, інформація про спожиту електроенергію, зчитана з лічильників АСКОЕ.

Виходячи з цього, набір первинних даних (для моделі - вхідних даних) можна описати як $\alpha_{1}\left(A_{1}, D_{1}, t\right), \quad \alpha_{2}\left(A_{2}, D_{2}, t\right), \ldots \alpha_{n}\left(A_{n}, D_{n}, t\right)$, де

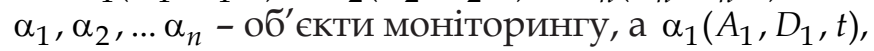
$\alpha_{2}\left(A_{2}, D_{2}, t\right), \ldots \alpha_{n}\left(A_{n}, D_{n}, t\right)-$ у свою чергу, є сукупністю аналогових та дискретних сигналів, наданих СМ, які являють собою зареєстровані в часі миттєві значення струму, напруги чи будь-яких інших параметрів, що реєструються розгалуже- ною системою датчиків та становлять інтерес для вирішення конкретного завдання управління. Причому розвиток СМ в електроенергетиці передбачає заміну аналогових сигналів цифровими [3].

Опираючись на загальні засади, наведені у праці [4], здійснимо опис функціонування інтелектуальної мережі електропостачання як багатовимірного об'єкта через модель (рис. 1), що являє собою комплекс окремих блоків та моделей, зокрема СМ і АСУ разом з його об'єктом, а також набір первинних даних, які надходять від CM, та набір керуючих рішень, які $є$ кінцевим результатом роботи АСУ та всієї інформаційнокомп' ютерної мережі загалом.

Зовнішній вплив на мережу електропостачання як об'єкт моніторингу та керування характеризується значеннями $\chi_{1}(t), \chi_{2}(t), \ldots \chi_{i}(t)$. Фактори, що описуються параметрами $\chi_{1}(t), \chi_{2}(t), \ldots \chi_{i}(t)$, детальніше розглянуто в праці [5].

Через «блок корекції (рис. 1) здійснюється зворотний зв' язок між об'єКтом моніторингу та керування 3 «модулем формування керуючих рішень». Виходами моделі $\beta_{1}(t), \beta_{2}(t), \ldots \beta_{m}(t)$ можуть бути параметри мережі електропостачання та/ або ії стан після застосування керуючих рішень.

Комплекс питань, пов'язаних 3 надійністю ефективного постачання електроенергії на тягу, тісно переплітається з проведенням в реальному часі оперативного моніторингу сукупності значень параметрів, що відображають режим функціонування системи електропостачання.

При порушеннях нормального режиму функціонування системи електропостачання аномальні процеси проходять 3 такою швидкістю, що зупинити їх шляхом втручання персоналу неможливо, тому й виникла необхідність в інтелектуалізованих системах діагностики. Для виконання функцій діагностики інформаційно-діагностичний комплекс «РЕГІНА» потребує лише інформації про нештатний режим роботи об'єкта моніторингу.

Головною при цьому є необхідність організації первинних даних у вигляді єдиного інформаційного простору мережі електропостачання, сформованого з єдиних загальносистемних позицій без проміжних вимірювальних перетворень [1]. Подібна організація інформації відкриває можливість використовувати ії всіма сегментами розподіленого комп'ютерного середовища керування електропостачанням, що значно покращує ряд показників якості функціонування мережі постачання електроенергії на тягу, безпеки руху і оптимізації електроспоживання. Найважливішими завданнями в процесі організації єдиного інформаційного простору є формування з єдиних загальносистемних позицій компонентів інфор- 


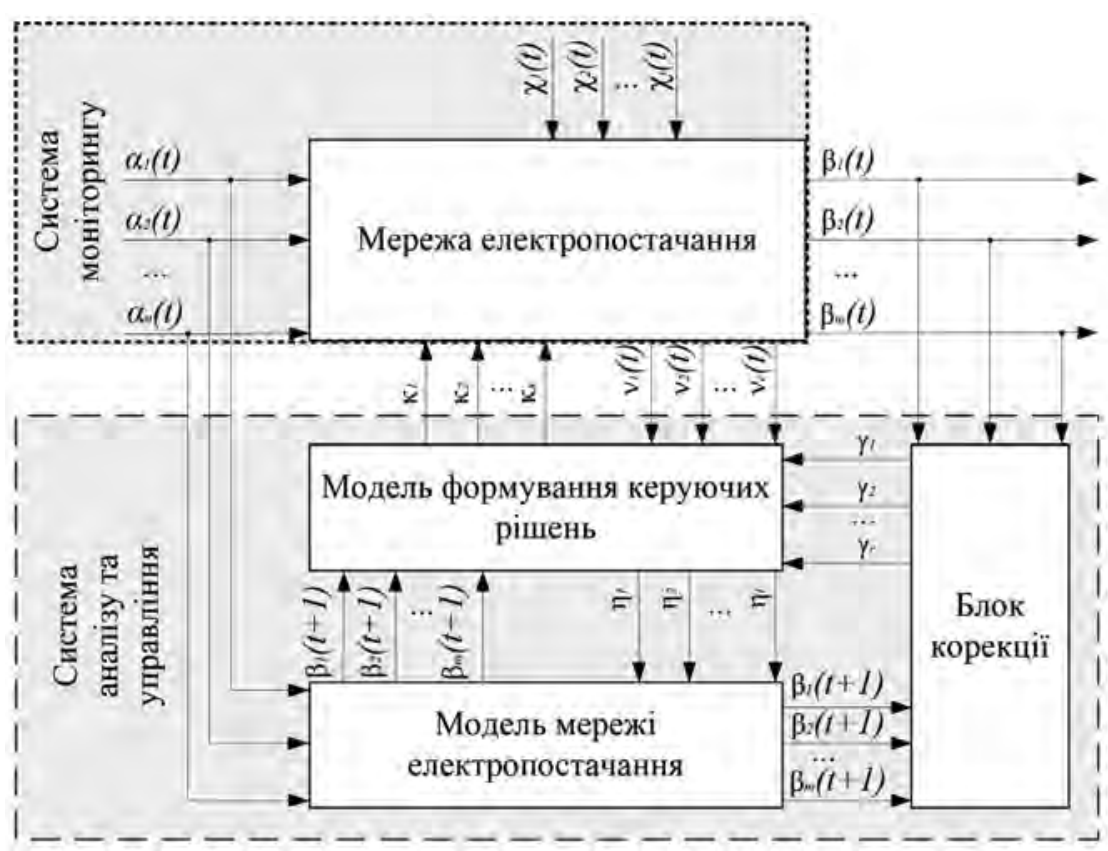

Рис. 1. Модель інформаційних потоків моніторингу та керування режимами роботи мережі електропостачання

маційного середовища, що для сукупності струмів $I_{k n}$ напруг $U_{k n}$ а також набору інших аналогових сигналів $A_{k e}$ може бути подано як:

$$
\begin{aligned}
& I_{k n}=\Phi_{k n}^{i}\left(I_{k e}^{d}, I_{k e}^{a}, I_{k e}^{p}, \tau, t, S_{k e}^{i}, C_{k e}^{i}, T\right) ; \\
& U_{k n}=\Phi_{k n}^{u}\left(U_{k e}^{d}, U_{k e}^{a}, U_{k e}^{p}, \tau, t, S_{k e}^{u}, C_{k e}^{u}, T\right) ; \\
& A_{k n}=\Phi_{k n}^{A}\left(A_{k e}^{d}, A_{k e}^{a}, A_{k e}^{p}, \tau, t, S_{k e}^{A}, C_{k e}^{A}, T\right),
\end{aligned}
$$

де $I_{k e}^{d}, U_{k e}^{d}, A_{k e}^{d}$ - сигнали доаварійного режиму;

$I_{k e}^{a}, U_{k e}^{a}, A_{k e}^{a}$ - сигнали аварійного режиму;

$I_{k e}^{p}, U_{k e}^{p}, A_{k e}^{p}$ - сигнали післяаварійного режиму;

$S_{k e}^{i}, S_{k e}^{u}, S_{k e}^{A}$ - параметри, які визначають синхронність реєстрації інформації у різних сегментах мережі електропостачання;

$C_{k e}^{i}, C_{k e}^{u}, C_{k e}^{A}-$ параметри, які визначають особливості організації первинної інформації з єдиних загальносистемних позицій;

$e$ - число дискрет за період $T$;

$k$ - кількість фідерів мережі електропостачання.

Набір дискретних сигналів $D_{k e}$ за аналогією 3 (1) може бути представлений системою математичних залежностей:

$$
D_{k e}=\Phi_{k n}^{D}\left(D_{k e}^{d}, D_{k e}^{a}, D_{k e}^{p}, \tau, t, S_{k e}^{D}, C_{k e}^{D}, T\right) .
$$

Сформуємо $I_{k e}, U_{k e}, A_{k e}, D_{k e}$ у вигляді множин відповідно як $\alpha^{i}, \alpha^{u}, \alpha^{A}, \alpha^{D}$, тоді:

$$
\left\{I_{k e}\right\} \in \alpha^{i},\left\{U_{k e}\right\} \in \alpha^{u},\left\{A_{k e}\right\} \in \alpha^{A},\left\{D_{k e}\right\} \in \alpha^{D} .
$$

На основі (1-3) модель єдиного інформаційного простору параметрів режимів мереж електропостачання залізниць у вигляді множини а відображається таким чином:

$$
\alpha=\alpha^{A} \cup \alpha^{D} \cup \alpha^{u} \cup \alpha^{i} .
$$

На основі математичних виразів (1-4) відкривається можливість організації ковзкого моніторингу параметрів режимів мереж електропостачання на тягу та різним споживачам. Завдяки тому, що первинна інформація $I_{k e}, U_{k e}, A_{k e}, D_{k e}$ поділяється на доаварійну, аварійну та післяаварійну, то для того щоб не записувати весь обсяг інформації доаварійного режиму та, відповідно, не завантажувати пам'ять, процес безперервного моніторингу реалізується таким чином. Значення первинних даних $I_{k e}^{d}, U_{k e}^{d}, A_{k e}^{d}, D_{k e}^{d}$ за $N$ періодів T частоти $f$ реєструється в пам'яті. Значення $I_{k e}^{d}, U_{k e}^{d}, A_{k e}^{d}, D_{k e}^{d}$ за $N+1$ період T записується в пам'ять на місце даних першого періоду, первинна інформація $I_{k e}^{d}, U_{k e}^{d}, A_{k e}^{d}, D_{k e}^{d}$ за $N+2$ період $T$, відповідно, записується в запам'ятовуючий пристрій на місце другого періоду і т. д. Так процес продовжується доти, поки за значеннями первинних даних $I_{k e}^{d}, U_{k e}^{d}, A_{k e}^{d}, D_{k e}^{d}$ згідно з відповідними критеріями не буде зареєстровано аварійний режим. Завдяки цьому повністю зберігається первинна інформація $I_{k e}^{d}, U_{k e}^{d}, A_{k e}^{d}, D_{k e}^{d}$ за $N$ періодів доаварійного режиму, повністю проводиться реєстрація інформації $I_{k e}^{a}, U_{k e}^{a}, A_{k e}^{a}, D_{k e}^{a}$ про аварійний режим синхронно за часом $t$, і роботою системи захисту i, врешті-решт, реєструються первинні дані $I_{k e}^{p}, U_{k e}^{p}, A_{k e}^{p}, D_{k e}^{p}$ післяаварійного режиму мережі електропостачання впродовж проміжку часу $\tau$.

У результаті проведення в реальному часі ковзкого режиму моніторингу при появі короткого замикання спеціалістам надається повна інформація про доаварійний $I_{k e}^{d}, U_{k e}^{d}, A_{k e}^{d}, D_{k e}^{d}$, аварійний $I_{k e}^{a}, U_{k e}^{a}, A_{k e}^{a}, D_{k e}^{a}$, а також післяаварійний $I_{k e}^{p}, U_{k e}^{p}, A_{k e}^{p}, D_{k e}^{p}$ режими для проведення аналізу й усунення неполадок. 
Цих категорій первинних даних цілком достатньо для ефективної роботи інформаційнодіагностичного комплексу. Такий підхід дозволяє заощаджувати апаратні ресурси комп'ютерної СМ та АСУ.

Впровадження корпоративної системи безперервного моніторингу й ідентифікації в реальному часі режимів мереж електропостачання залізниць забезпечить комплексне вирішення таких завдань: підвищення рівня надійності та ефективності функціонування системи електропостачання залізниці, суттєве поліпшення безпеки руху потягів і підтримки рішень диспетчерського і технологічного персоналу щодо формування керуючих впливів [5-7]. На різних ієрархічних рівнях комп'ютерної системи управління ЕM ПАТ «Укрзалізниця» інтегрованою корпоративною системою реалізуються відповідні функції, а саме: забезпечується реєстрація доаварійних, аварійних та післяаварійних режимів функціонування електричних мереж із синхронізацією за часом та спрацьовуваннями систем захисту, реалізація мікропроцесорного захисту, визначення місця аварії та ідентифікація характеру пошкодження, комерційний облік електричної енергії за тарифами, диференційованими за зонами доби, технологічний облік електричної енергії за окремими фідерами, первинна обробка звітної інформації. Крім того, реалізується формування та передавання на вищі рівні керування експресінформації або повної інформації.

\section{Висновки}

1. Проведено аналіз існуючих методів оперативного управління режимами електропостачання тягових електричних мереж залізниць, на базі якого накреслено шляхи побудови математичних моделей та комп'ютерно-орієнтованих методів організації ковзкого моніторингу бистроплинних технологічних процесів постачання електроенергії і моделей для опису аномальних режимів системи електропостачання.

2. Запропоновано модель систем моніторингу та керування режимами роботи мережі електропостачання як взаємопов' язаних складових єдиного інформаційного простору. Показано інформаційні зв' язки між компонентами систем моніторингу та керування і їхнім об'єктом, зокрема узагальнену структуру перетікання первинних даних, керуючих рішень та зовнішніх впливів у межах інформаційно-комп'ютерної системи.

3. Запропоновано математичну модель організації ковзкого моніторингу параметрів режимів мережі електропостачання залізниць і способи організації синхронно зареєстрованих первинних даних та способи формування їх у вигляді єдиного інформаційного простору із загально- системних позицій як основи оптимізації енергопостачання, покращання безпеки руху і реалізації енергозберігаючих технологій.

\section{Бібліографічний список/References}

1. Стасюк О. I. Методи організації комп'ютерної мережі моніторингу параметрів режимів систем електропостачання / О. І. Стасюк, Л. Л. Гончарова, В. Ф. Максимчук // Інформаційно-керуючі системи на залізничному транспорті. - 2012. - № 2. - С. 35-40.

Stasyuk O. I., Goncharova L. L., Maksymchuk V. F. (2012). Metody organizaciyi komp'yuternoyi merezhi monitoryngu parametriv rezhymiv system elektropostachannya [Methods of computer network organization for monitoring power supply systems modes parameters]. Informatsiino-keruiuchi systemy na zaliznychnomu transporti [Information and control systems on the railway transport]. No. 2, pp. 35-40.

2. Стогній Б. С. Основи моніторингу в електроенергетиці. Про поняття моніторингу / Б. С. Стогній, М. Ф. Сопель // Техн. електродинаміка. - 2013. - № 1. - С. 62-69.

Stognij B. S., Sopel M. F. (2013). Fundamentals of monitoring process in electroenergy. About the concept of monitoring process. Technical electrodynamics. No. 1 , pp. 62-69.

3. Бобало Ю. Я. Моніторинг об’єктів в умовах апріорної невизначеності джерел інформації / Ю. Я. Бобало, Ю. Г. Даник, Л. О. Комарова та ін. Львів, 2015. - 360 с.

Bobalo Yu. Ya., Danyk Yu. H., Komarova L. O. (2015). Monitorynh obiektiv v umovakh apriornoi nevyznachenosti dzherel informatsii [Monitoring of objects in a priori uncertainty of sources of information]. $360 \mathrm{p}$.

4 Гайденко О. С. Характерні особливості моделювання системи та процесів тягового електропостачання залізниці як об'єкта моніторингу та керування / / О.С.Гайденко, Г. М. Голуб // Моделювання та інформаційні технології: зб. наук. праць ІПМЕ ім. Г. Є. Пухова НАН України. - 2017. - № 79. - С. 42-48.

Haidenko O. S., Golub G. M. (2017). Kharakterni osoblyvosti modelyuvannya systemy ta protsesiv tyahovoho elektropostachannya zaliznytsi yak obyekta monitorynhu ta keruvannya. Modelyuvannya ta informatsiyni tekhnolohiyi IPME im. H. Ye. Pukhova NAN Ukrayiny. No. 79, pp. 42-48.

5. Kulbovskyi I. I., Golub G. M. (2016). Doslidzhennya ta analiz normatyonoyi ta normatyonotekhnichnoyi dokumentatsiyi, yaki zabezpechuyut' informatsiynu bezpeku SMART GRID system. Informatsiyno-keruyuchi systemy na zaliznychnomu transporti. No. 3, pp. 50-57.

6. Кульбовський I. I. Дослідження та аналіз нормативної та нормативно-технічної документації, 
які забезпечують інформаційну безпеку SMART GRID систем / I. I. Кульбовський, Г. М. Голуб // Інформаційно-керуючі системи на залізничному транспорті. - 2016. - № 3. - С. 50-57.

Kulbovskyi I. I., Golub G. M. (2016). Doslidzhennya ta analiz normatyonoyi ta normatyono-tekhnichnoyi dokumentatsiyi, yaki zabezpechuyut' informatsiynu bezpeku SMART GRID system. Informatsiynokeruyuchi systemy na zaliznychnomu transporti. No. 3, pp. 50-57.

7. Sapronova S. Yu. Real Vehicles: The Resistance to the Movement and Controllability: Monograph / S. Yu. Sapronova, V. P. Tkachenko, O. V. Fomin, I. I. Kulbovskyi, E. P. Zub. - Dnipro: Ukrmetalurginform STA, Akcent PP, 2017. - 160 p.

Sapronova S. Yu., Tkachenko V. P., Fomin O. V., Kulbovskyi I. I., Zub E. P. Real Vehicles: The Resistance to the Movement and Controllability. Dnipro: Ukrmetalurginform STA, Akcent PP, 2017, $160 \mathrm{p}$.

Цель. Разработка модели инфрормационных потоков компьютерного мониторинга и управления как неотъемлемых составляющих единого инорормационного пространства хозяйства электроснабжения железной дороги; совершенствование математических методов организации непрерывного мониторинга параметров функционирования сетей железной дороги в процессе поставки электроэнергии на тягу поездов для проведения, контроля работы электрических сетей и оборудования, идентификации аварийных и нормальных режимов работы электрических сетей в режиме реального времени.

Методика. Разработка и моделирование информационной системы компьютерного мониторинга и улучшения контроля работы электрических сетей и оборудования, идентифрикации аварийных и нормальных режимов работы электрических сетей в режиме реального времени.

Результаты. Разработана модель систем мониторинга и управления режимами работы сети электроснабжения, показывающая информационные связи между компонентами систем и их объектом, а также способы организации синхронно зарегистрированных первичных данных, формирования их в виде единого информационного пространства.

Научная новизна. Для проведения контроля работы электрических сетей и оборудования, идентификации аварийных и нормальных режимов работы электрических сетей в режиме реального времени предложена математическая модель организации скользящего мониторинга параметров режимов сети электроснабжения железных дорог и способы организации синхронно зарегистрированных первичных данных и формирования их в виде единого информационного пространства с общесистемных позиций как основы оптимизации энергоснабжения, улучшения безопасности движения и реализации энергосберегающих технологий.

Практическая значимость. Решение проблемы оптимизации энергоснабжения, улучшение безопасности движения и реализация энергосберегающих технологий.

Ключевые слова: системный анализ, энергосбережение, автоматизированная система управления, модель, компьютерный мониторинг, информационные потоки, идентифрикация, технологический процесс.

Purpose. Development of the model of information flows of computer monitoring and control as integral components of a single information space of the railway power supply industry; Improvement of mathematical methods for organizing continuous monitoring of parameters of operation of railway networks in the process of supplying electric power to traction of trains for carrying out, control of operation of electric networks and equipment, identification of emergency and abnormal operating modes of electric networks in real time.

Methodology. Development and modeling of the information system of computer monitoring and improvement of control over the operation of electrical networks and equipment, identification of emergency and abnormal modes of operation of electric networks in real time.

Result. The model of systems of monitoring and control of the modes of operation of the power supply network is developed, which shows the information communications between the components of the systems and their object, as well as methods of organizing synchronously registered primary data, forming them in the form of a single information space.

Originalityty. For conducting, controlling the operation of electrical networks and equipment, identifying emergency and abnormal modes of operation of electric networks in real time, a mathematical model of organization of slippery monitoring of parameters of modes of electricity supply of railways and methods of organizing synchronously registered primary data and ways of forming them in the form of a single information space is proposed. from system-wide positions as the basis for optimization of energy supply, improvement of traffic safety and implementation of energy saving s technology.

Practical value. Solving the problem of optimizing energy supply, improving traffic safety and implementing energy-saving technologies.

Key words: system analysis, energy saving, automated control system, model, computer monitoring, information flows, identification, technological process.

\section{Рекомендована к публикации д. т. н. В. Я. Савенко}

Поступила 8.10.2018 